\title{
Cutaneous tuberculosis and squamous-cell carcinoma *
}

\author{
Tuberculose cutânea e carcinoma de células escamosas
}

\author{
Milanka S Ljubenovic ${ }^{1}$ \\ Ivana I Binic ${ }^{3}$ \\ Snezana A Jancic ${ }^{5}$
}

\author{
Dragisa B Ljubenovic ${ }^{2}$ \\ Aleksandar S Jankovic ${ }^{4}$
}

\begin{abstract}
The incidence of all forms of cutaneous tuberculosis, including lupus vulgaris (the most common form) decreased progressively in developed countries during the twentieth century, this change being attributed to improved living standards and specific therapy. Despite the decrease in cutaneous tuberculosis, some cases are still found and correct diagnosis and management are fundamental, both for the patients and for public health. Long lasting, misdiagnosed or untreated cutaneous tuberculosis may lead to different forms of cancer. This case report involves a 74 -year old male farmer with lupus vulgaris on his face. During anti-tuberculosis treatment he developed a tumor on his forehead, which was histologically confirmed as a squamous cell carcinoma. Keywords: Carcinoma; Skin cancer; Tuberculosis, cutaneous

Resumo: A incidência de todas as formas de tuberculose cutânea, incluindo o lúpus vulgar (a forma mais comum) diminuiu progressivamente nos países desenvolvidos durante o século XX e esta mudança foi atribuída a melhores condições de vida e uso de terapia específica. Apesar da diminuição da TBC cutânea, alguns casos ainda são detectados hoje em dia e o diagnóstico acurado e o tratamento apropriado são fundamentais para os doentes e a saúde pública. A TBC cutânea quando prolongada, diagnosticada erroneamente ou não tratada pode levar a diferentes neoplasias. Este é o relato de um caso de lúpus vulgar na pele do rosto de uma paciente do sexo masculino, agricultor, de 74 anos de idade. Durante a terapia antituberculosa ele desenvolveu um tumor na pele da testa, histologicamente confirmado como carcinoma de células escamosas.

Palavras-chave: Carcinoma; Neoplasias cutâneas; Tuberculose cutânea
\end{abstract}

\section{INTRODUCTION}

The incidence of all forms of cutaneous tuberculosis (TB), including lupus vulgaris (the commonest form), has been progressively decreasing in developed countries during the twentieth century and this change has been attributed to improved living standards and specific therapy. In spite of this decrease in the incidence of cutaneous tuberculosis, some cases are still found and adequate diagnosis and management must be ensured, this being fundamental both for the patients and for public health. Long lasting, misdiagnosed or untreated cutaneous tuberculosis could lead to the development of a variety of types of cancer.

\section{CASE REPORT}

A 74-year old male patient was referred to this clinic with a diagnosis of discoid lupus erythematosus. He had lesions bilaterally in the preauricular region, on his left ear, on the left side of his forehead and on his left forearm (Figure 1). The lesions appeared as sharply demarcated, irregular, brownish-red plaques and the patient's left ear lobe was of the same, brownish-red color and noticeably swollen. He complained of mild itching. His skin lesions had been present for three years and he had been treated with antibiotic and corticoid ointments to no avail.

Recebido em 04.04.2010.

Aprovado pelo Conselho Consultivo e aceito para publicação em 19.06.2010.

* Study conducted at the Clinic of Dermatovenereology, Nis, Serbia and Stomatology Clinic, Department of Maxillofacial Surgery, Nis, Serbia.

Conflito de interesse: Nenhum / Conflict of interest: None

Suporte financeiro: Nenhum / Financial funding: None

Dermatovenereologist, Head of the Photolaser and Physiotherapy Department, Clinic of Dermatovenereology, Nis, Serbia

MD. Head of the Anesthesiology and Reanimatology Unit, Department of Maxillofacial Surgery, Stomatology Clinic, Nis, Serbia.

PhD. Professor of Dermatovenereology, Nis Medical School, Serbia.

$\mathrm{PhD}$. Dermatovenereologist, Nis Clinic of Dermatovenereology, Serbia.

Professor of Pathology, Kragujevac School of Medicine, Serbia

(C)2011 by Anais Brasileiros de Dermatologia 


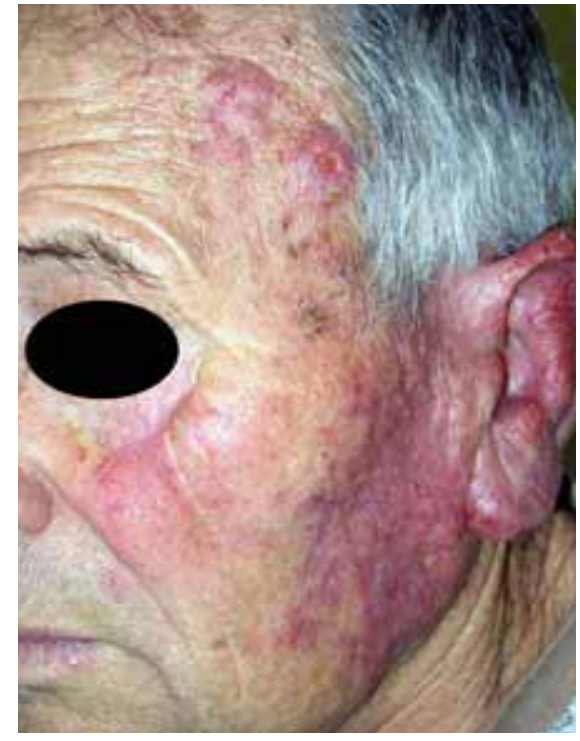

Figure 1: Skin

lesions on the face prior to treatment
At diascopy, the plaques turned an apple-jelly color. Routine laboratory tests were normal except for an above-normal erythrocyte sedimentation rate of $32 \mathrm{~mm} /$ hour. Chest radiography was normal. Tuberculin test (PPD) was positive with a $20 \mathrm{~mm}$ induration. Direct microscopy and cultures from the lesion, sputum and urine were all negative for Mycobacterium tuberculosis (MT). Histopathology of the lesion on the forearm revealed a granulomatous tubercle with epithelioid cells, Langhans giant cells and a mononuclear infiltrate (Figures 2, 3).

The patient reported a history of a squamouscell carcinoma on his right forehead that had been removed four years previously, and a basal-cell carcinoma in the left malar region that had been removed

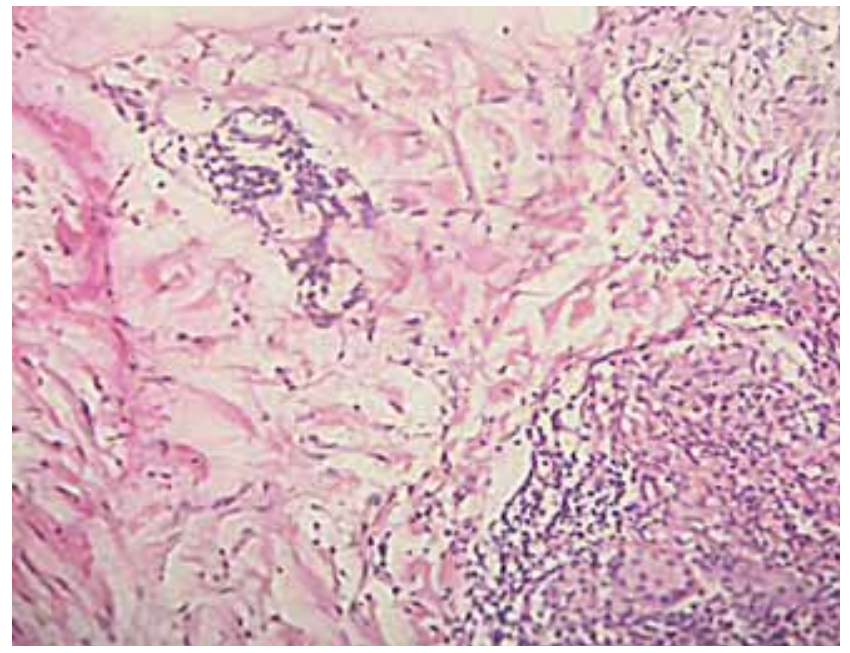

Figure 3: Magnification of the same image shown in Figure 2

twenty-five years earlier. Neither of these tumors had involved the parts of the skin affected by the present lesions and both had been confirmed histologically.

The patient's father had pulmonary tuberculosis and his uncle (his father's brother) had died as a young man from pulmonary tuberculosis.

A diagnosis of cutaneous tuberculosis was established and treatment was initiated with three antibiotics, rifampicin, isoniazid and pyrazinamide, for the first two months followed by rifampicin and isoniazid for a further four months.

Regression of the skin lesions was remarkable; however, at a routine follow-up visit four months after initiation of therapy, a rapidly growing tumorous lesion was found on the patient's forehead and tem-

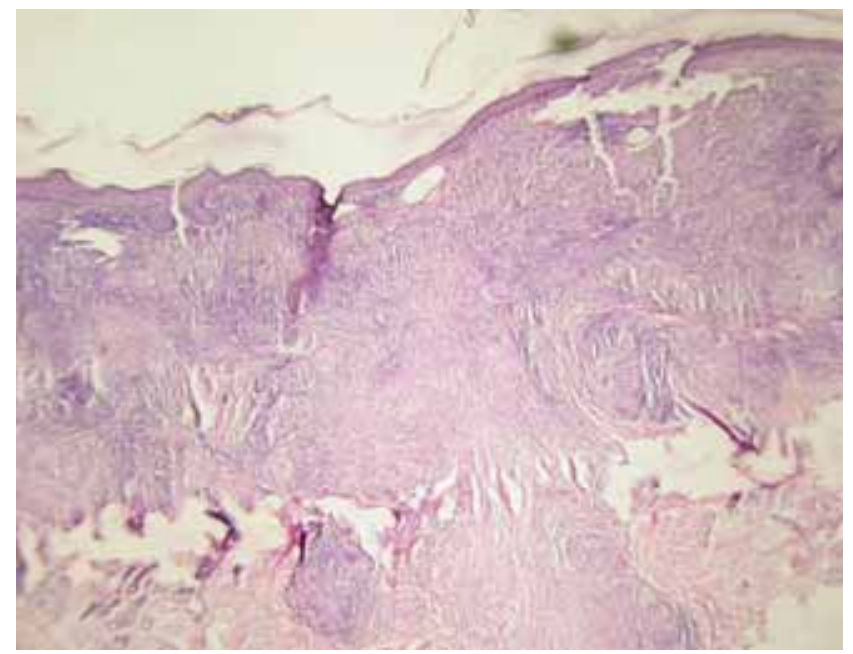

FigURE 2: Histopathology findings of a granulomatous tubercle with epithelioid cells, Langhans giant cells and a mononuclear infiltrate

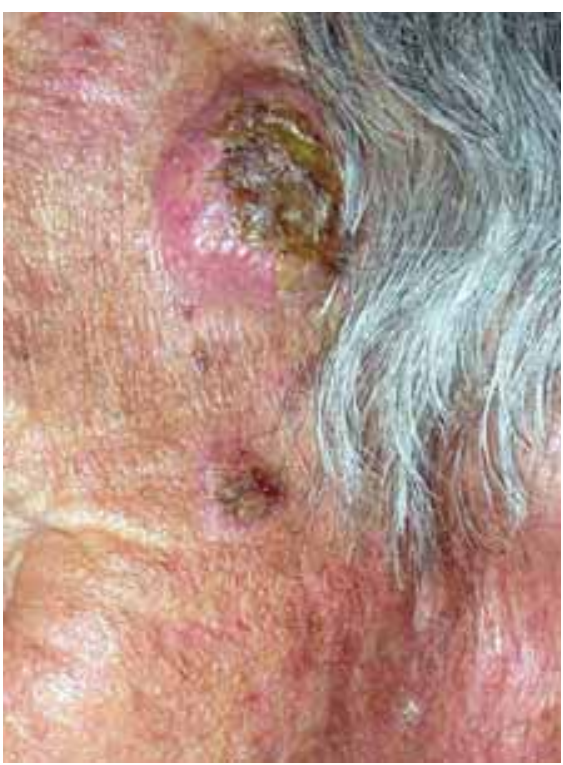

Figure 4:

Tumorous, rapidly growing lesion on the skin, appearing four months after initiation of antituberculosis therapy 
poral region adjacent to a tuberculous plaque (Figure 4). The patient was referred to the Department of Maxillofacial Surgery for surgical treatment. A large excision was performed and histopathology revealed a squamous cell carcinoma of the skin (Figure 5). The tumor was completely removed. The patient recovered from surgery and the treatment for tuberculosis was continued.

\section{DISCUSSION}

Cutaneous tuberculosis is caused by Mycobacterium tuberculosis, Mycobacterium bovis, and under certain conditions, the bacillus CalmetteGuérin (BCG) ${ }^{1,2}$.

Lupus vulgaris is a chronic and progressive form of secondary cutaneous tuberculosis that occurs in tuberculin-sensitive patients. In most series, it is the most common form of cutaneous TB and its presentation is the most variable ${ }^{1}$. Lesions appear in normal skin as a result of the direct extension of underlying foci of tuberculosis, by means of lymphatic or hematogenous dissemination, following primary inoculation of Mycobacterium tuberculosis, BCG vaccination or secondary to scarring from scrofuloderma. Historically, lupus vulgaris was most prevalent in northern Europe, with the number of affected females outnumbering males by two or three to one.

Lesions are generally single, and involve the head and neck in over $90 \%$ of cases. Small, red-brown papules of gelatinous consistency (apple-jelly nodu-

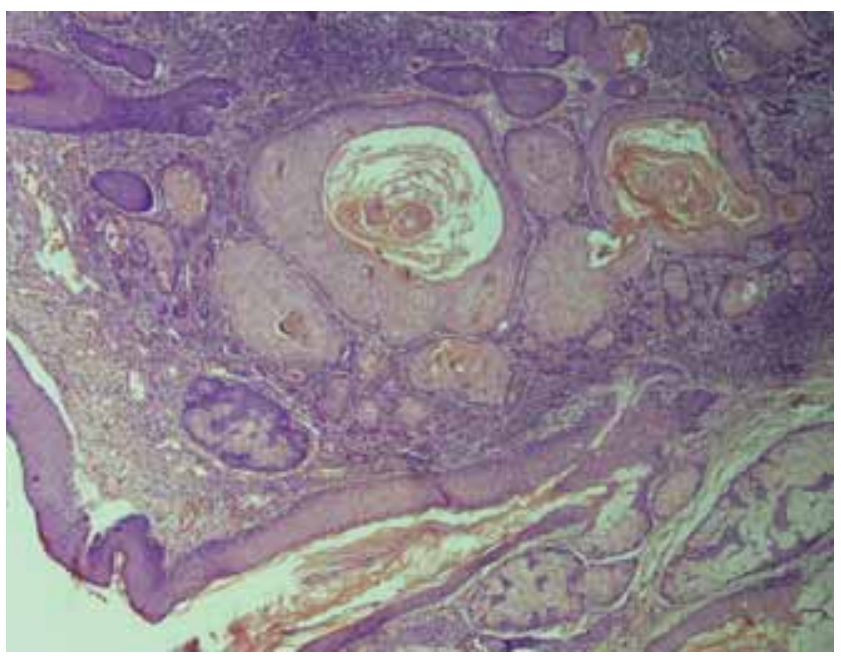

FIGURE 5: Histopathology of squamous-cell carcinoma on the forehead les) and with sharply defined margins slowly evolve by peripheral extension and central atrophy into large plaques. The appearance of new nodules within previously atrophic or scarred lesions is characteristic. Cartilage (nose, ears) within the affected area is progressively destroyed (lupus vorax); however, bone is usually spared. Buccal, nasal, and conjunctival mucosa may be involved primarily or by extension.

The quantity of bacilli encountered in cutaneous tuberculosis is small ${ }^{1}$. Because lupus vulgaris is a paucibacillary form of tuberculosis infection, culture is often negative and the diagnosis is based mainly on the Mantoux test, histopathological appearance and response to chemotherapy. In recent years, polymerase chain reaction techniques have been developed that may be able to detect Mycobacterium tuberculosis DNA in the tissues ${ }^{3,4}$.

Lupus vulgaris represents a type of cutaneous tuberculosis that, if not correctly treated, develops progressively and chronically and whose long-term complications include skin cancer, predominantly squamous-cell carcinoma. The incidence of this complication was estimated to be $10 \%$ in the early 20 th century; however, a review of the literature revealed only a few cases in recent times ${ }^{5-7}$. Basal-cell carcinomas and sarcomas are less common $(\leq 8 \%)^{1}$. There have been occasional reports of various types of cutaneous malignancies developing on lupus vulgaris lesions ${ }^{8}$.

Squamous-cell carcinoma (SCC) constitutes around $20 \%$ of all skin malignancies. It consists of an atypical proliferation of squamous cells of an invasive nature, which can produce metastases. As a rule, primary cutaneous SCCs originate in sun-exposed areas of the body, and there is no doubt that chronic and cumulative exposure to UV radiation, particularly UVB, is the primary cause of skin cancer ${ }^{9}$.

The patient in this case report had several risk factors for skin cancer (chronic UV exposure, cutaneous TB), and he had already had several types of skin cancer during his lifetime, two prior to the clinical appearance of cutaneous tuberculosis. All the tumors occurred on sun-exposed areas; however, the most recent tumor consisted of a squamous-cell carcinoma on skin that had been affected by cutaneous tuberculosis.

It is impossible to determine the importance of this specific risk factor alone; however, the present case underlines the importance of risk factors for skin cancer, as well as other problems associated with a disease that has almost been forgotten, thus often resulting in misdiagnosis. 


\section{REFERENCES}

1. Yates VM, Honorary FRCP. Mycobacterial Infections In: Burns T, Breathnach S, Cox N, Griffiths C, editors. Rook's Textbook of Dermatology.7th ed. Oxford: Blackwell Science; 2004. p.10-18. 28.

2. Afsar FS, Afsar I, Diniz G, Asilsoy S, Sorguc Y. Lupus vulgaris in a pediatric patient: a clinicohistopathological diagnosis. Braz J Infect Dis. 2008;12:152-4.

3. Arora SK, Kumar B, Sehgal S. Development of a polymerase chain reaction dot-blotting system for detecting cutaneous tuberculosis. $\mathrm{Br} J$ Dermatol. 2000;142:72-6.

4. Barbagallo J, Tager P, Ingleton R, Hirsch RJ, Weinberg JM. Cutaneous tuberculosis: diagnosis and treatment. Am J Clin Dermatol. 2002;3:319-28.

5. Aktan S, Gokalan KI, Demirkan N, Berna S. Squamous Cell Carcinoma Developing Over Lupus Vulgaris. The Internet Journal of Dermatology [Internet]. 2001 [cited 2011 Apr 15];7: Available from: http://www.ispub.com/journal/the_internet_ journal_of_dermatology/volume_7_number_1_18/article/squamous_cell_ carcinoma_developing_over_lupus_vulgaris.html

6. Haller D, Reisser C. Lupus vulgaris manifestation as a destructive nose and facial tumor. HNO. 2009;57:364-7.

7. Motswaledi MH, Doman C. Lupus vulgaris with squamous cell carcinoma. J Cutan Pathol. 2007;34:939-41.

8. Kanitakis J, Audeffray D, Claudy A. Squamous cell carcinoma of the skin complicating lupus vulgaris. J Eur Acad Dermatol Venereol. 2006;20:114-6.

9. Martinez MAR, Francisco G, Cabral LS, Ruiz IRG, Festa Neto C. Genética molecular aplicada ao câncer cutâneo não melanoma. An Bras Dermatol. 2006;81:405-19.
ENDEREÇO PARA CORRESPONDÊNCIA / MAILING ADDRESS:

Milanka S Ljubenovic

Clinic of Dermatology and Venereology, Clinical

Center Nis

Blvd dr Zorana Djindjica 48

18000 Nis Serbia

Telepbone: 381646157965

E-mail: milanka_ljubenovic@yaboo.com

How to cite this article/Como citar este artigo: Ljubenovic MS, Ljubenovic DB, Binic II, Jankovic AS, Jancic AS. Cutaneous tuberculosis and squamous-cell carcinoma. An Bras Dermatol. 2011;86(3):541-4. 